UNITED STATES OEPARTMENT OF THE INTERIOR

GEOLOGICAL SURVEY

PRELIMINARY GEOTECHMICAL AND GEOPHYSICAL LOGS FROM

DRILL HOLE 2C-80 IN THE CAPPS COAL FIELD,

COOK INLET REGION, ALASKA

By

Alan F. Chleborad, Lynn A. Yehle, Henry R. Schmoll, Cynthia A. Gardner, and Larry L. Dearborn

Open-File Report $82-884$

1982

This report is preliminary and has not been reviewed for conformity with U.S. Geological Survey editorial standaros and stratigraphic nomenclature. Any use of trade names is for descriptive purposes only and does not imply endorsement by the USGS.

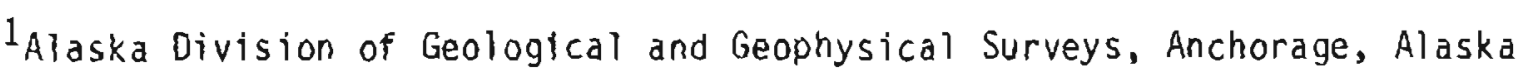




\section{CONTENTS}

Page

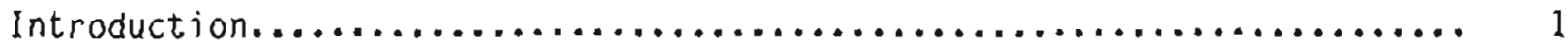

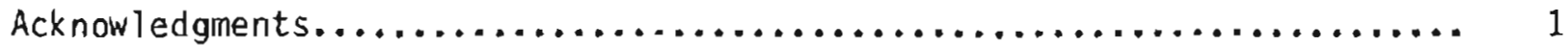

Drilling operation..................................... 5

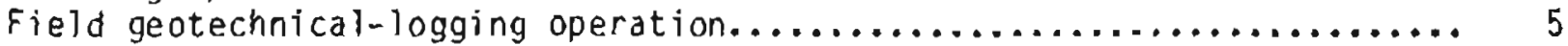

Summary of geotechnical properties.......................... 5

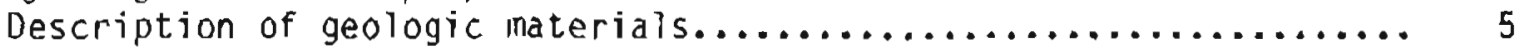

Discontinuities and weathering.......................... 6

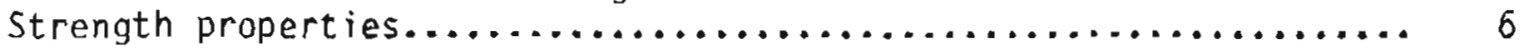

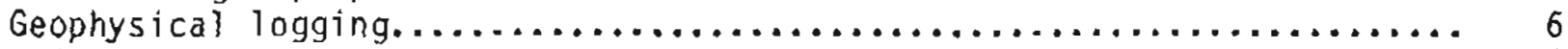

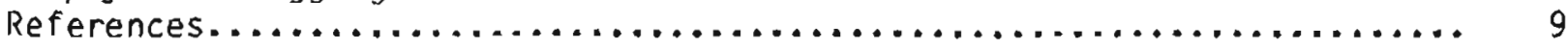

\section{ILLUSTRATIONS}

Page

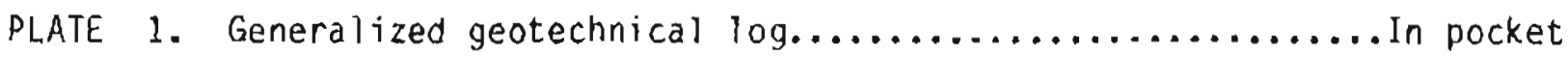

2. Compilation of geophysical, lithographic,

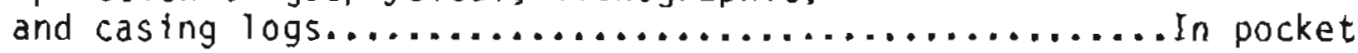

FIGURE 1. Index map showing location of drill site $20-80 \ldots \ldots \ldots \ldots \ldots . . .2$

2. Location of drill site $1 C-79$ and drill site 2C-80

in relation to the geology and proposed

mine areas...................................... 3

3. Generalized lithologic log for drill hole $2 C-80 \ldots \ldots \ldots \ldots . . .4$

4. Relationship between hardness and unconfined compressive strength............................ 7 


\title{
PRELIMINARY GEOTECHNICAL AND GEOPHYSICAL LOGS FROM DRILL HOLE 2C-80 IN CAPPS COAL FIELD, COOK INLET REGION, ALASKA
}

\author{
By Alan F. Chleborad, Lynn A. Yehle, henry R. Schmoll, \\ Cynthia A. Gardner, and Larry L. Dearborn
}

\section{INTRODUCTION}

The drilling and logging information provided in this report was collected during September 1980 as part of the Energy Lands program of the U.S. Geological Survey.

Drill hole $2 \mathrm{C}-80$ is located in the Capps Coal Field, approximately $100 \mathrm{~km}$ (62 mi) west of Anchorage, Alaska (fig. 1). The arilling was undertaken to obtain information on the geotechnical characteristics of a part of the coalbearing Tyonex formation and overlying surficial deposits. The preliminary results of a previous drill hole $(1 \mathrm{C}-79)$, located $1.3 \mathrm{~km}(0.8 \mathrm{mi})$ northeast of drill hole 2C-80, were reported by Chleborad and others (1980).

The Tyonek Formation is early Otigocene to middle Miocene in age (Wolfe and Tanai, 1980). At the drill site it is overlain by a thin colluvial deposit of Quaternary age.

The drilling and continuous core sampling penetrated $19.5 \mathrm{~m}(63.9 \mathrm{ft})$ of overburden, a major coal bed (Waterfall bed), and approximately $29 \mathrm{~m}$ (95.1 ft) of underlying material, to a total depth of $61 \mathrm{~m}(200 \mathrm{ft})$. Drill hole $2 \mathrm{C}-80$ stratigraphically overlaps drill hole 1C-79 and continues down section approximately $33 \mathrm{~m}(108 \mathrm{ft})$.

A proposed open pit codimining plan (Placer Amex, Inc., 1977, status report of December 1977) outlines a sequential mining and reclanation scheme for flue areas in the Capps Coal Field. Figure 2 shows the location of drill holes $2 \mathrm{C}-80$ and $1 \mathrm{C}-79$ with respect to the proposed mining areas as well as selected surface features. A general description of the geology and natural hazards of the region are given by Schmoll and others (1981).

The generalized lithology interpreted from core obtained from drilling and supplemented by outcrop mapping accomplished during the 1979 and 1980 field seasons is presented in figure 3 . A more detailed lithologic log is presented as part of the geotechnical log.

The geotechnical and geophysical logs presented herein (pis. 1 and 2) provide basic physical-property and engineering data useful in predicting the response of geologic materials to proposed large-scale coal mining and related development, and in identifying and assessing potential geologic hazards.

\section{Acknow jedgments}

The authors are grateful for the support, technical advice, and assistance of colleagues P. S. Powers, G. L. Nelson, and R. W. Nichols. The Beluga Coal Company generously contributed geophysical logs and various geologic and geographic information useful in planning the drilling operation. He thank Cook Inlet Region, Inc., owners of the land, for permitting access to the area. 


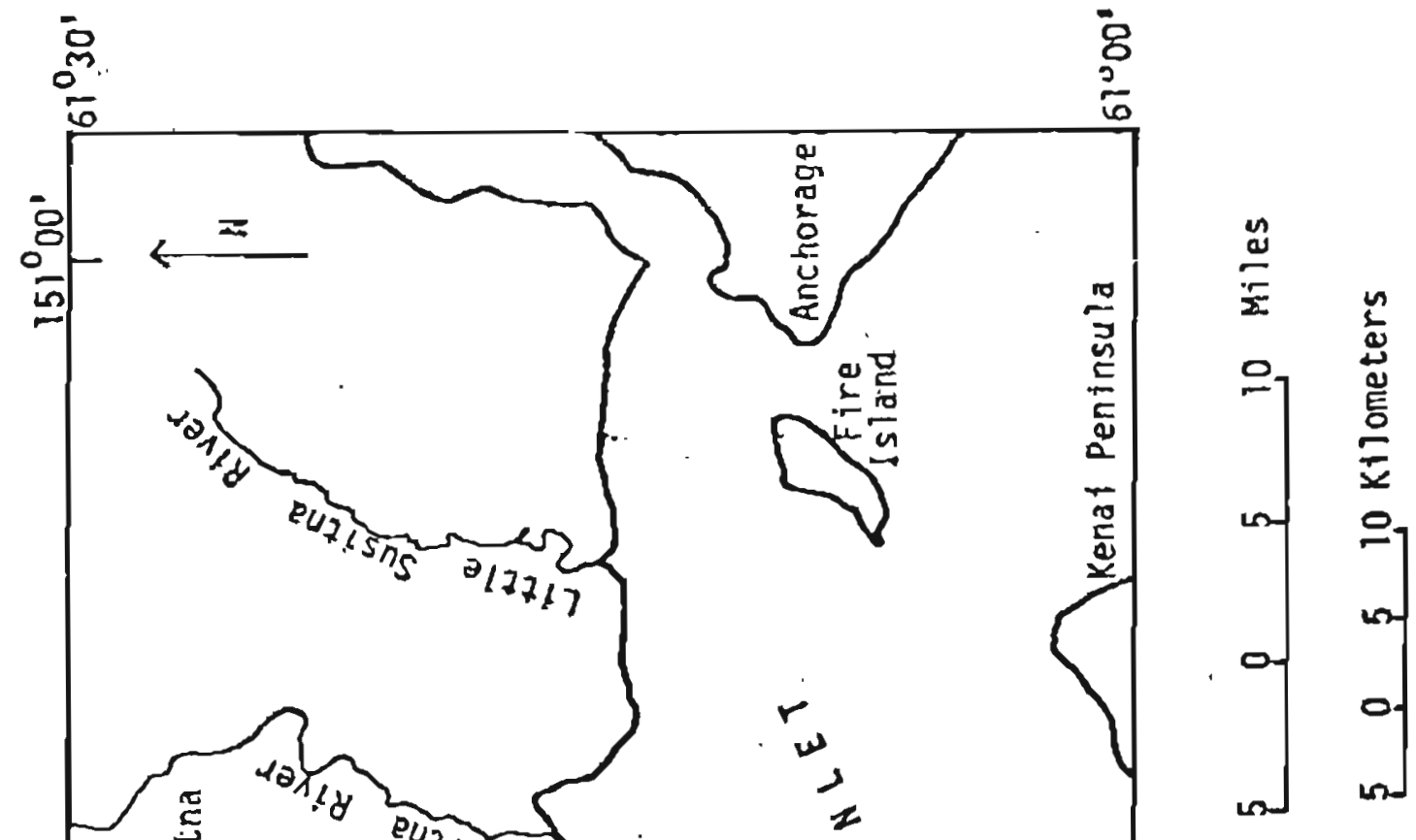




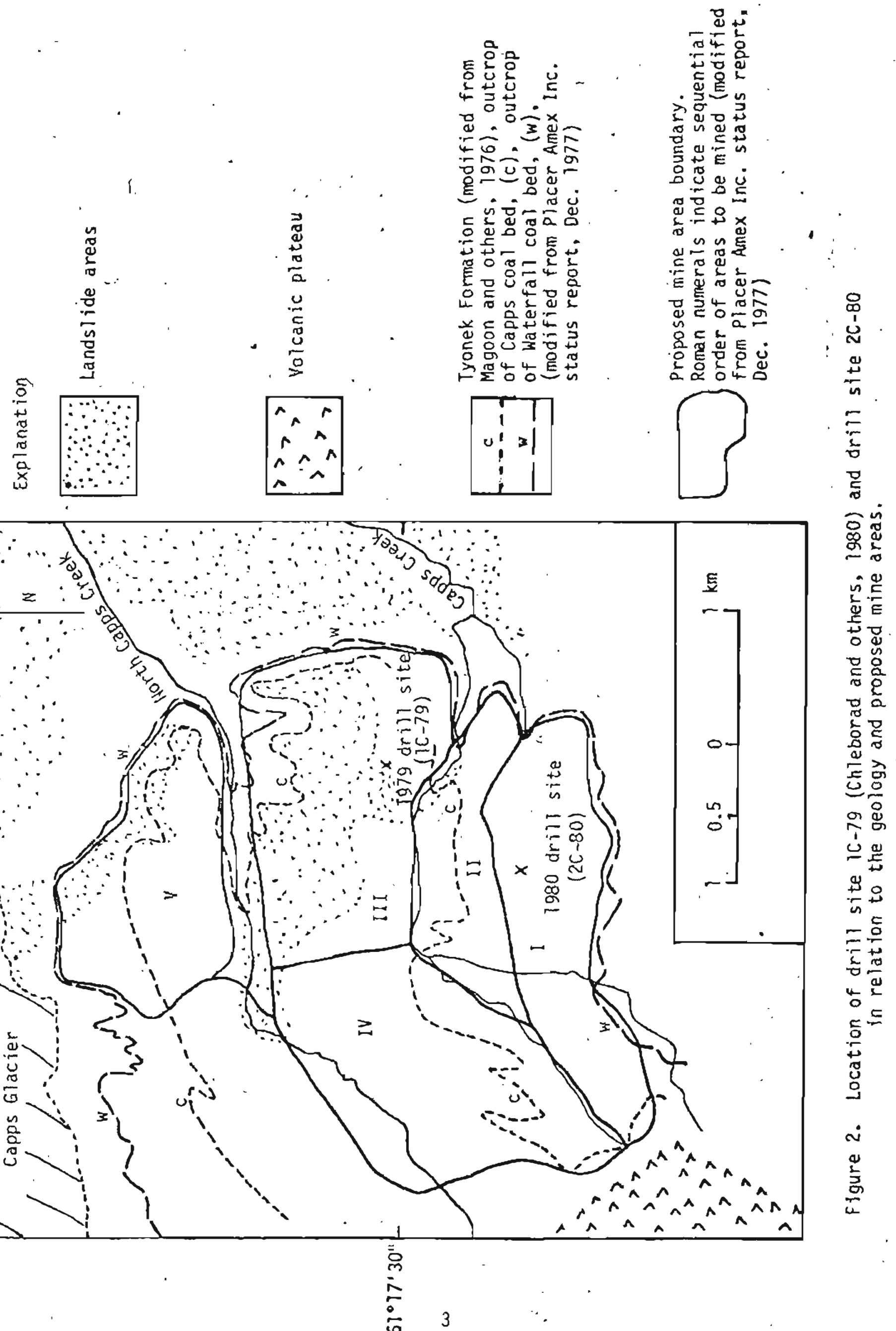




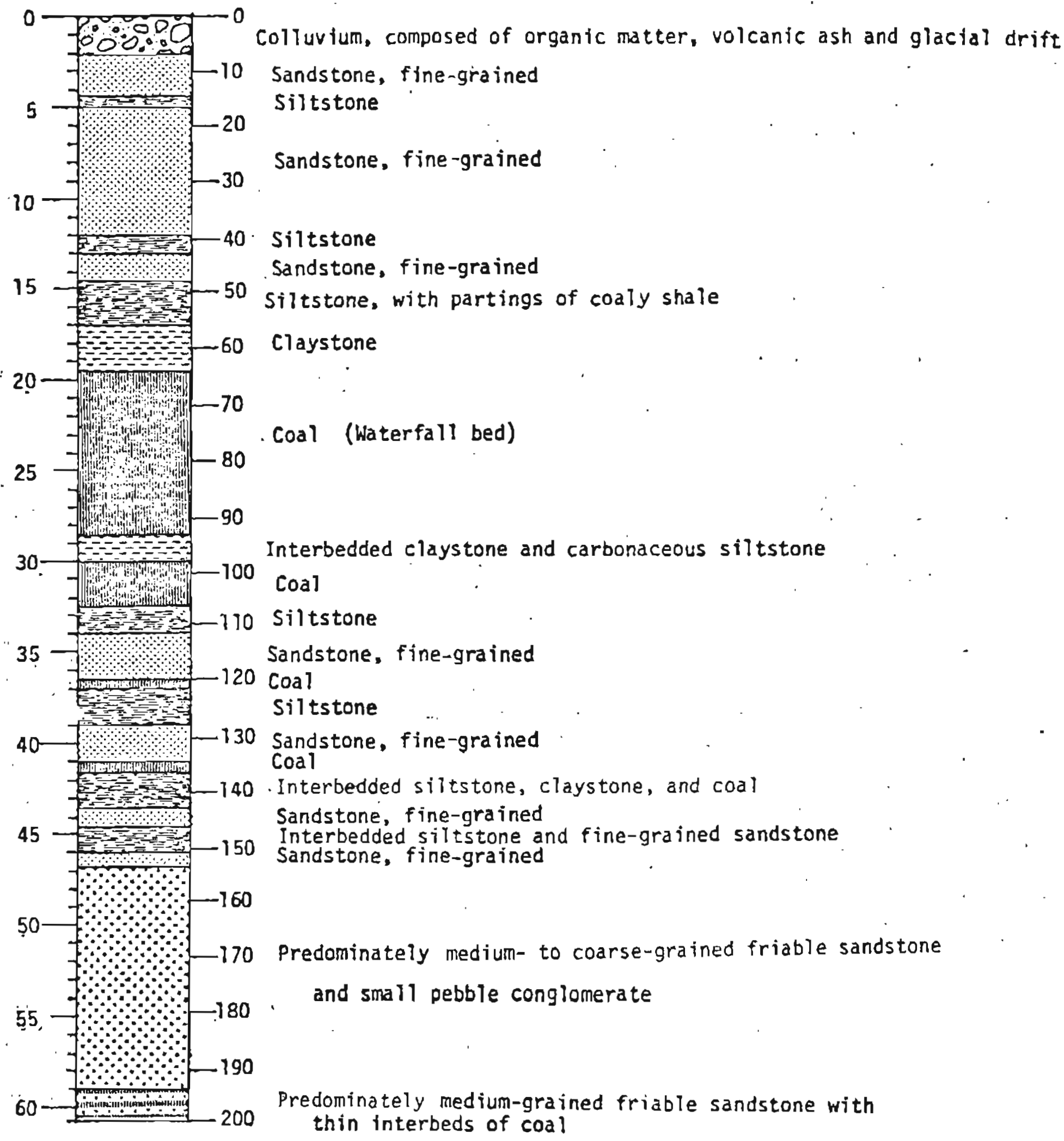

Figure 3. Generalized lithologic log for drill hole $2 C-80$. 


\section{DRILLING OPERATION}

A Gardner-Denver Model 2000 drill rig equipped with a rotary $H Q$ wire 1 ine core system (6.4-cm- $(2.5-i n .-)$ diameter core size) was used to obtain continuous core suitable for logging and physical-property testing. Diamond core bits were used on a $1.5-\mathrm{m}-(5.0-\mathrm{ft}-)$ long HQ core barrel with split-tube inner barrel. Drilling mud additives were used starting at a depth of approximately $50 \mathrm{~m}$ (164 ft) to stop a loss of drilling fluid. Drilling of the 60.6-m- (200-ft-) deep, near-vertical drill hole was completed in approximately 6 days.

\section{FIELD GEOTECHNICAL-LOGGING OPERATION}

The procedure for retrieving, logging, testing, and packaging the core was simflar to that described for drill hole $1 \mathrm{C}-79$ (Chleborad and others, 1980). The core was washed, photographed, and described using an abbreviated field-logging scheme (Rankilor, 1974). Field tests included the pocket penetrometer (Soiltest, Inc., 1978), and point-load (Broch and Franklin, 1972) strength-index tests, moisture-content determination tests, and a carbonatedetection test. The core (except for the coal) was wrapped in cheesecloth and waxed for transport and storage. Coal samples were sealed in plastic sleeves and further sampling and strength-indices tests were performed in Denver. Test results and descriptions of the core are presented in generalized form on plate 1.

\section{SUMMARY OF GEOTECHNICAL PROPERTIES}

\section{Description of Geologic Materials}

Sandstone, siltstone, coal, and claystone are the principal lithologies sampled at the site.

The sandstones above $49 \mathrm{~m}$ (160 ft) in depth range in color from pale yel lowish brown (weathered) to medium gray and contain mostly fine to very fine subrounded to subangular grains. The bedding ranges from massive to obscurely bedded to laminated, and generally exhibits gradational contacts. Below $49 \mathrm{~m}$ (160.8 ft) the sandstone is medium light gray to medium gray, medium to coarse grained, and very friable.

Siltstone is medium dark gray, grayish brown (where weathered), massive to obscurely bedded or laminated, commonly clayey or sandy, and occasionally carbonaceous.

Claystones are medium gray to medium dark gray, massive to obscurely bedded or laminated, silty, and often carbonaceous.

Coal beds are brownish black to black, and are massive with partings or interbeds of siltstone or claystone.

Unconsolidated silty sand and clayey silt of probable colluvial origin extend from the surface to a depth of nearly $2 \mathrm{~m}(6.6 \mathrm{ft})$; however a few pebbles were also present. The colluvium probably was derlved from siltstone, sandstone, and glacial drift. The colluvium also includes a mantle of volcanic ash and some organic matter totaling about $1 \mathrm{~m}(3.3 \mathrm{ft})$ in thickness. 
All materials sampled were noncalcareous.

\section{Discontinuities and weathering}

Discontinuities in bedrock include joints, bedding break separations, and broken rock zones. The discontinuities shown on plate 1 include both natural and drilling induced fractures; often it was difficult to distinguish between the two. Those discontinuities indicated as joints are believed to be natural fractures.

Weathering is believed to extend to a depth of approximately $11 \mathrm{~m}$ $(36.1 \mathrm{ft}$ ) on the basis of: (1) discoloring related to iron-oxide stain, (2) the apparent oxidation (depletion) of carbonaceous materials, and (3) low strength values (pl. 1). Many of the joints above $11 \mathrm{~m}(36.1 \mathrm{ft}$ ) are marked by tron-oxide stain indicating that they are avenues for the inflltration of surface waters (p1. 1).

\section{Strength Properties}

Unconfined compresstve strength values were calculated from point-load tests (Franklin and others, 1972). The materials excluding coal, range in strength from 0.24 to $7.44 \mathrm{MPa}$ (megapascal) and can be classified as ranging from soft soil to soft rock (fig. 4). Calculated compressive strengths of coal samples varied greatly with values as high as $21.6 \mathrm{MPa}(p 1.1)$.

The preponderance of relatively low strengths indicate that much of the matertal can be easily excavated. Such material, however, may be easily eroded and may contribute to slope-stability problems if not adequately evaluated and designed for in the mining plan.

\section{GEOPHYSICAL LOGGING}

Natural gamma radiation, gamma-gamma radiation, neutron radiation, caliper, spontaneous potential, single-point resistance, and temperature measurements were run in the hole soon after completion of coring.

A Well Reconnaissance, single-conductor cable, suitcase-slzed logger was used following techniques described by Keys and MacCary (1971). A compilation of the geophysical logs with lithologic and casing logs are shown on plate 2.

The geophysical-log responses document almost all lithologic contacts. In genera1, interpretatyon of the sulte of logs reinforces the subtle descriptive differences noted on the lithologic log. The more important interpretative features are briefly discussed below.

Washouts or hole diameter enlargements, due to caving of loose or friable beds along the drill hole, occur fairly commonly above the water level. Radiation logs, run inside the drill stem before it was removed, reflect major washed-out intervals. The largest deflection on each log occurred between $10.7 \mathrm{~m}(35 \mathrm{ft})$ and $13.7 \mathrm{~m}(45 \mathrm{ft})$, and these large deflections are mainly the result of an unintentional "window" in the surface casing. Apparently, the lower $3 \mathrm{~m}(10 \mathrm{ft})$ of casing became unscrewed and 51 ipped down $2.1 \mathrm{~m}$ (7 ft). The most direct measurement of hole-size variations is the caliper log, which was run after the drill stem was removed. 


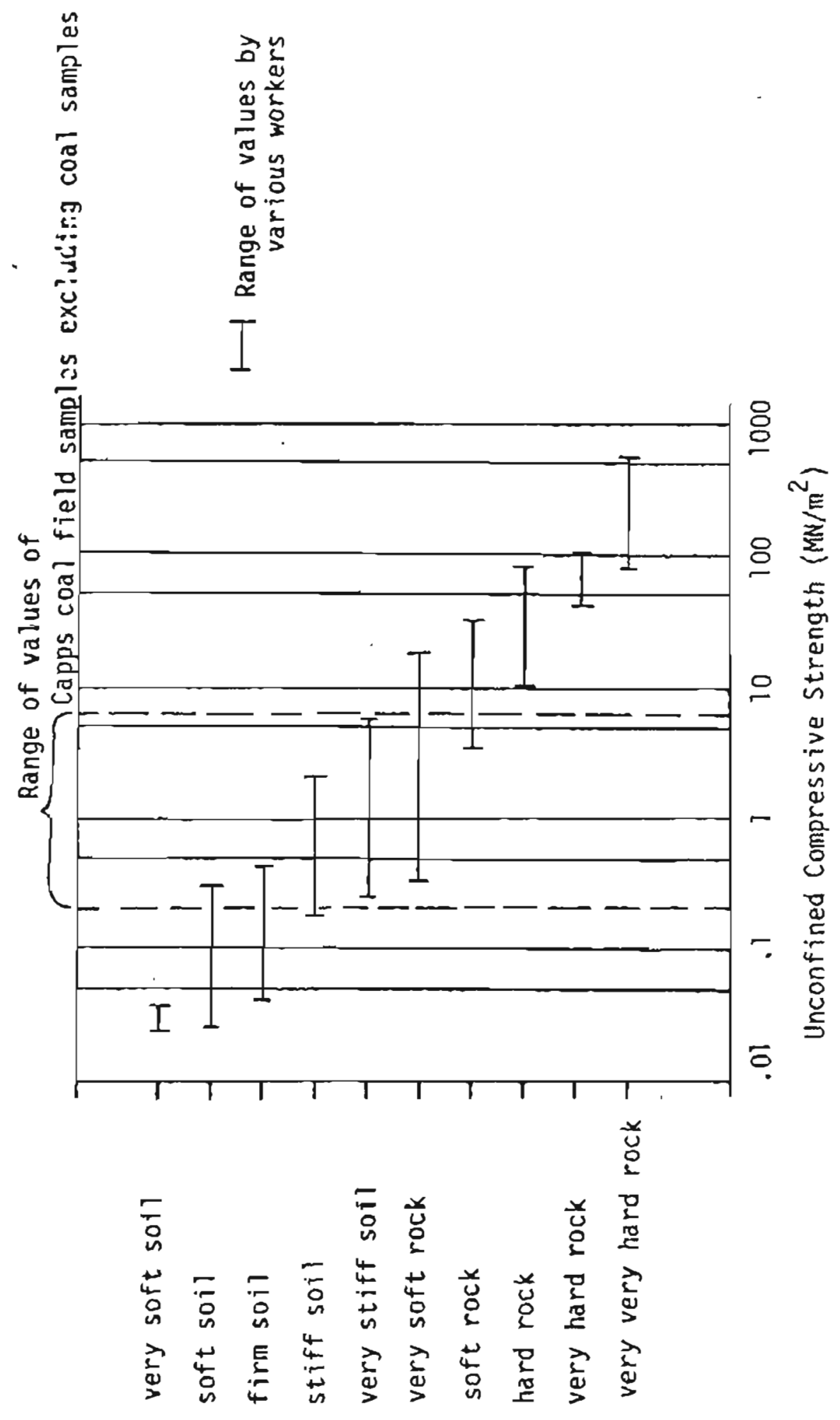

$\frac{5}{0}$
$\frac{E}{0}$
$\frac{1}{2}$

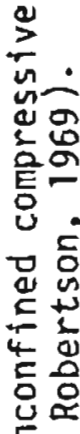

号

읃

जू

is.

독 동

도 틍

둔

究 임

岩

을을

등

$\frac{\pi}{\alpha}$

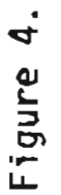


All coal beds within the logged interval, except for a very thin bed at $40.2 \mathrm{~m}(132 \mathrm{ft})$, caused conspicuous deflections on the radiation logs. These responses are a result of a very low natural-gamna radiation level; a low backscatter level on the neutron log because of the abundance of hydrogen molecules; and relatively low density indicated by a marked increase in the gamma-gamma count rate.

Deflections characteristic of coal beds are also generally present on the spontaneous potential and resistance logs, which begin below water level $33.5 \mathrm{~m}$ (110 ft) because of instrument limitations. The thinness of coal beds below this depth caused much less deflection than would have been registered by the much thicker coal beds at shallower depth.

The suite of geophysical logs, especially the natural-gamma and electric logs, strongly indicate that beds below a depth of $47.2 \mathrm{~m}$ (155 ft) for which no core was retrieved, are probably composed of relatively clean granular materlal-most likely medium or coarse-grained sandstones. It is recognized in this interpretation that the abrupt and pronounced rightward shift on the gamma-gamma log at $56.1 \mathrm{~m}$ (184 ft) is due to the lower termination of the drill stem, and not to any recognizable decrease in buik density. The other radiation logs also reflect the constructional change in the driti hole, but to a lesser degree.

The temperature $\log$ was run several hours after drilling ceased and presumably after temperature effects fram drilling had largely dissipated. The only pronounced shift on the $10 \mathrm{~g}$, at $49.7 \mathrm{~m}(163 \mathrm{ft}$ ), may be due to downward flow of water within the drill hole. The highly sensitive and finely calibrated thermistor-type probe detected a rapid temperature increase of over $0.5^{\circ} \mathrm{C}\left(32.9^{\circ} \mathrm{F}\right)$ below this depth. A warmer, nearly constant temperature of $3.3^{\circ} \mathrm{C}\left(37.9^{\circ} \mathrm{F}\right.$ ) occurred below $50.3 \mathrm{~m}$ (165 ft). Water thought to be entering the hole above $32.9 \mathrm{~m}$ (108 ft) probably was moving downward and out into a

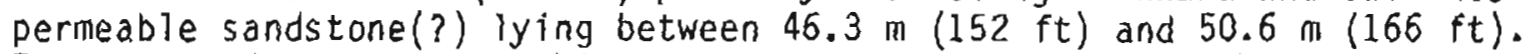
Further evidence of permeability of this zone is found on the other geophysical logs as well-marked deflections. 


\section{REFERENCES}

Broch, E., and Franklin, U. A., 1972, The point-load strength test: International Journal of Rock Mechanics and Mining Sciences, v. 9, no. 6, p. 669-697.

Chleborad, A. F., Yehle, L. A., Schmoll, H. R., and Gardner, C. A., 1980, Preliminary fleld geotechnical and geophysical logs from a drlll hole in the Capps coal field, Cook Inlet region, Alaska: U.S. Geological Survey Open-File Report 80-393, 20 p.

Franklin, J. A., Broch, E., and Walton, G., 1972, Logging the mechanical character of the rock: Institution of Mining and Metallurgy Transactions, p. A43-A51.

Jennings, J. E., and Robertson, A., 1969, The stability of slopes cut into natural rock: Internatyonal Conference Soil Mechanics and Foundation Engineering, 7th, Mexico, Proceedings, v. 2, p. 585-590.

Keys, W. S., and MacCary, L. M., 1971, Application of borehole geophysics to water-resources investigations, Chapter El: U.S. Geological Survey Techniques of Water-Resources Investigations TWI 2-El, $126 \mathrm{p}$.

Placer Amex, Inc., 1977, Beluga Coal Project status report, December 1977: Unpublished information obtained from Placer Amex, Inc., Suite 2500, One California Building, San Francisco, California 94111, $56 \mathrm{p.}$

Rankilor, P. R., 1974, A suggested field system of logging rock cores for engineering purposes: Association of Englneering Geologists Bulletin, v. 11 , no. 3 , p. 247-258.

Schmol1, H. R., Chleborad, A. F., Yehle, L. A., Gardner, C. A., and Pasch, A D., 1981, Reconnaissance engineering geology of the Beluga coal resource area, southcentral Alaska, in Rao, P. O., and Wolff, E. N., Focus on Alaska's Coal ' 80 Conference, Fairbanks, Alaska, October 21-23, 1980, Proceedings: University of Alaska MIRL Report 50, p. 92-ilo.

Solltest, Inc., 1978, Pocket penetrometer operating details--Soiltest model CL-700: Soiltest, Inc., 2205 Lee Street, Evanston, Illinois, 60202, Bulletin 151-64, [pamphlet].

Wolfe, J. A., and Tanai, Toshimasa, 1980, The Miocene Seldovia Point flora from the Kenai Group, Alaska: U.S. Geological Survey Professional Paper 1105,52 p. 